\section{Race Relations:}

Adjustment of Whites and Negroes in the United States. By Prof. Willis D. Weatherford and Prof. Charles S. Johnson. (Heath Social Relations Series.) Pp. $x+590$. (Boston, New York and London: D. C. Heath and Co., 1935.) 15s. net.

Wirh Miss Cunard's encyclopædic anthology ("Negro", Wishart, 1934), this book deserves the serious attention of all students of Negro problems. Distinguished by a graceful style, it provides a general survey of the philosophy of ethnic relations, a crisp account of American slavery and its effects on the body-politic, and a review of the present status of the Negro in the American 'melting pot', which together form the best concise history of Afroamerican development known to the reviewer. An extensive bibliography completes the volume.

The social object of the authors is to stimulate mutual tolerance, and they regard their own work, the first sociological text-book written jointly by a white man and a Negro, as "a concrete expression of racial cooperation and, they believe, of racial goodwill and understanding". They are accordingly careful not to offend the susceptibilities of American 'liberalism', the Negro author by confining himself to objective statement, the white by occasional indulgence in moralising and special pleading which would have been better excluded from a work of professedly scientific purpose. Such propaganda does, of course, attract 'sympathy' ; but it also antagonises those who, like the reviewer, believe in a rational approach to social problems.

It is not surprising, therefore, to find Prof. Weatherford emphasising the popular compromise of 'parallel racial development' (while his colleague stresses the impossibility of a separate Afroamerican culture) in a country where racialism is already more obviously ludicrous than in any other. To-day, the 'purest' Afroamerican cannot establish freedom from comparatively recent white or Indian admixture, while the supposedly white Americans have been exten. sively impregnated with Negroid or Mongoloid genes during the last three centuries.

C. D.

L'Organisation de l'œuf chez les chordés: étude d'embryologie causale

Par Prof. Albert Dalcq. (Collection des Actualités biologiques.) Pp. viii +322 . (Paris : GauthierVillars, 1935.) 65 francs.

THIs is an interesting exposition of modern work on the organisation of the egg in the Chordata. Beginning with the researehes of Conklin on the normal development of Styela and of Amphioxus, the author proceeds to describe and discuss the development of isolated blastomeres of Ascidians and Amphioxus. $\mathrm{He}$ then gives an account of the normal development of Amphioxus and an analysis of the investigations designed to elucidate the organisation of the amphibian egg. The experimental work on the latter subject up to 1930 forms the subject of one chapter, which is followed by an admirable chapter of about sixty pages on the results in this domain published between 1930 and 1933. The tabular presentation and classi- fication of the researches in the experimental embryology of Amphibia, especially of the Urodola, is useful. A chapter is devoted to a consideration of the organisation of the eggs of fishes, birds and mammals. In a final chapter, the views on ontogeny due to Goldschmidt, Lillie and Wintrebert are presented and discussed.

The whole work is notoworthy for clearness of presentation. It contains one hundred illustrations, including three plates in colour, and a classified bibliography; but there is no index.

\section{The Two Sources of Morality and Religion}

By Henri Bergson. Translated by R. Ashley Audra and Cloudesley Brereton, with the assistance of W. Horsfall Carter. Pp. viii +278 . (London : Macmillan and Co., Ltd., 1935.) 10s. net.

For years past, it has been a learned game among philosophers to attempt the formulation of a Bergsonian ethics on the basis afforded by the metaphysical and psychological works of the author of "Creative Evolution". The game is now over; for Bergson himself has given the world a most inspiring and unexpected sketch of his ethical views, in a fundamental work of which we have now this excellent translation.

Bergson does not pretend to give his readers any special rules of conduct, but merely to discuss the true bearings of the fundamental concepts of morality and the distinctive functions of static and dynamic religion. This discussion is not merely academic, but involves also all the concepts which are operative in our modern problems. The most remarkablo conclusion of this analysis is perhaps Bergson's plea for asceticism and a science of the spirit as the necessary counterpart to centuries of material progress. As to the merits of the present translation, a comparison with the original French shows readily that in spite of the difficulties of the undertaking, the translators have given an excellent rendering of this epochmaking work.

T. G.

\section{Handbuch der Experimentalphysik}

Herausgegeben von W. Wien und F. Harms. Band 17, Teil 1: Schwingungs- und Wellenlehre, Ultraschallwellen. Bearbeitet von E. Grossmann, H. Martin, H. Schmidt. Pp. $\mathrm{x}+561$. (Leipzig : Akademische Verlagsgesellschaft, m.b.H., 1934.) 45 gold marks.

THIs volume of the "Handbuch" is in three parts. The first part, by H. Martin, deals with the theory of oscillations, and includes mechanical, acoustical and electrical methods of production, conditions for stability, oscillations of coupled circuits, overtones and undertones. The second part, by Harry Schmidt, is a full survey of unidimensional, two-dimensional and three-dimensional problems of wave-motion. In the third part, E. Grossmann discusses the subject of supersonics ; methods of production and reception of supersonic waves, their propagation, absorption and their mechanical, chemical and physiological effects are detailed in turn. The references are as usual, extensive. 